УДК 661.6

\author{
А.В. Сибір ${ }^{1}$, М.В. Губинський ${ }^{2}$, С.С. Федоров ${ }^{1}$, С.М. Губинський ${ }^{2}$, О.Г. Гогоці ${ }^{1}$ \\ 1 - Національна металургійна академія України \\ 2 - Товариство з обмеженою відповідальністю «ТЕРМАЛ ЕНД МЕТІРІАЛ ЕНЖІНІРІНГ СЕНТЕР»
}

\title{
ПЕЧІ 3 ЕЛЕКТРОТЕРМІЧНИМ КИПЛЯЧИМ ШАРОМ. КОНСТРУКТИВНІ ОСОБЛИВОСТІ
}

\begin{abstract}
В на основі критичного аналізу конструкцій печей з електротермічним киплячим шаром, які використовуються у низько- та високотемпературних технологічних процесах у металургійній та хімічний промисловості, запропонована їх класифікація. Класифікація проведена за рівнем температур термічної обробки, напрямку струму у робочому просторі печі, розташуванням електродів, особливостям конструкції щодо подачі сировини та вивантаження готової продукції, подачі газу до киплячого шару, а також визначення конструктивних особливостей цих пічних агрегатів.
\end{abstract}

DOI: $10.34185 / 0543-5749.2020-2-42-61$

\section{Ветуп}

Безумовною перевагою реалізації технологічних процесів високотемпературної металургії і хімії (пряме відновлення оксидів заліза, отримання карбідів, збагачення вуглецевих матеріалів, газифікація та активація вугілля $\mathrm{i}$ т.п.) в агрегатах 3 киплячим шаром $\epsilon$ можливість інтенсифікації тепло і масообміну на основі потокових високопродуктивних технологій $[1-2]$.

Під високотемпературними ми розуміємо процеси в діапазоні температур $1000-3000{ }^{\circ} \mathrm{C}$, які вимагають підведення теплової енергії для компенсації теплових втрат та підтримки необхідної температури у ендотермічних процесах. Джерелами енергії можуть бути гарячий газ, що надходить в реактор як зріджуючий агент, пряме спалювання твердого або газоподібного палива безпосередньо у шарі, а також електричний нагрів. 3 практичного досвіду [2 - 4] використання гарячих продуктів згоряння або спалювання безпосередньо у шарі забезпечують роботу печей при температурах до $900-$ $1200{ }^{\circ} \mathrm{C}$. Тому основним методом високотемпературної обробки в киплячому шарі залишається електричний нагрів, який, у свою чергу, включає декілька способів реалізації: індукцій- ний нагрів, плазмовий нагрів, нагрів електронагрівачами і резистивний нагрів електропровідних частинок киплячого шару (електротермічний киплячий шар).

Електротермічний киплячий шар (ЕКШ) забезпечує роботу печей при температурах в діапазоні $1000-3000{ }^{\circ} \mathrm{C}$, при цьому тривалість обробки не обмежена і дозволяє організувати безперервний виробничий процес. Основні принципи його організації полягають у наявності як мінімум двох електродів; електропровідного матеріалу та джерела струму (рис. 1).

Вибір варіанту реалізації ЕКШ та відповідний вибір вогнетривів визначаються рівнем температури процесу. У зв'язку з цим, всі технологічні процеси і конструкції печей можна умовно розділити на: «низькотемпературні» температура шару $1000-1600{ }^{\circ} \mathrm{C}$; «високотемпературні» - температура шару $1600-$ $3000{ }^{\circ} \mathrm{C}$.

У «низькотемпературних» печах можуть бути використані вогнетривкі матеріали [5, 6] - шамотні, корундові, магнезіальні, динасові. Для «високотемпературних» печей - графіт. Саме це обмеження визначає конструкцію печі і організацію технологічного процесу.

(C) Сибір А.В., Губинський М.В., Федоров С.С., Губинський С.М., Гогоці О.Г., 2020 


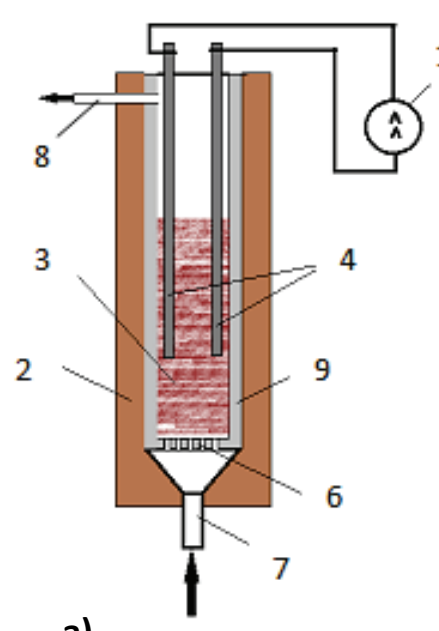

a)

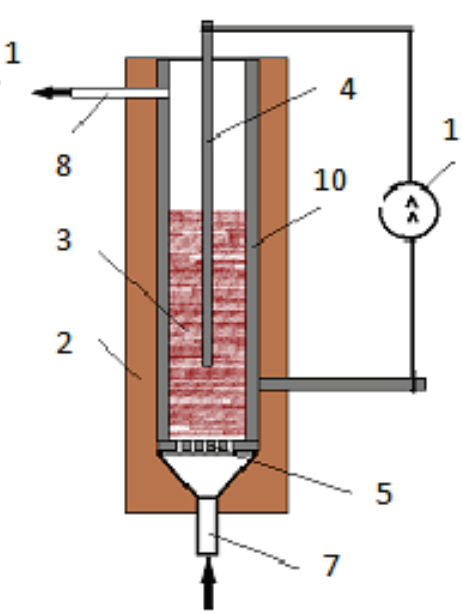

b)

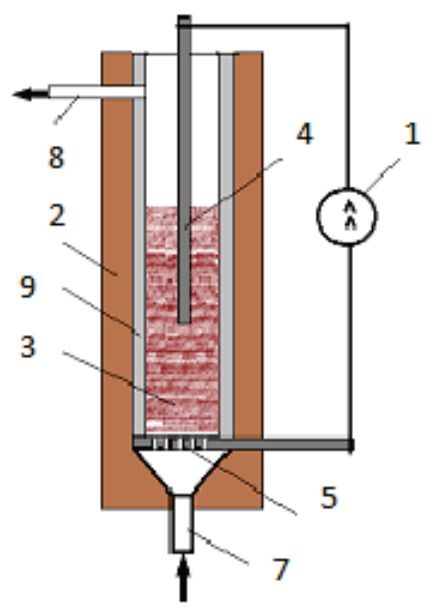

c)

Рис. 1. Варіанти реалізації електротермічного киплячого шару [1]: а) з двома зануреними електродами; b) 3 одним центральним електродом та електропровідною футеровкою; с) 3 одним центральним електродом та електропровідною решіткою: 1 - джерело струму; 2 - корпус 3 тепловою ізоляцією; 3 - киплячий шар; 4 - електрод; 5 - газорозподільна решітка - електрод; 6 - газорозподільна решітка; 7 - підвід інертного газу; 8 - видалення газів 3 печі; 9 - неелектропровідна футеровка робочої камери; 10 - електропровідна футеровка робочої камери печі

\section{Методика}

Дослідження особливостей конструкції та систематизація науково-технічної інформації проводилися на основі критичного аналізу досвіду використання та розробки печей з ЕКШ. Розробка наукових основ створення цих печей та технологічних процесів з ЕКШ приходяться на семидесяті роки минулого сторіччя, але практичне їх використання було не дуже широким, бо конкурентні технології на основі щільного шару та викопного палива мали на той час свої переваги. Однак перехід на сталий розвиток виробництва з використанням відновлювальних та нетрадиційних джерел енергії звернули увагу на електротермічні процеси, які можуть бути основою створення «зелених» високотемпературних технологій. Так процеси термічної обробки дисперсних матеріалів без їх розплавлення мають перспективи використання печей ЕКШ. Це підтверджено на сам перед для високотемпературного очищення графіту інтерес до якого значно виріс в останні роки.

\section{Результати та їх обговорення}

\section{«Низькотемпературні» печі з ЕКШ}

До «низькотемпературних» процесів в ЕКШ можна віднести: пряме відновлення заліза 3 використанням твердого вуглецевого матеріалу в якості відновника [7], отримання карбіду титану $\mathrm{TiC}[8]$, карбіду кремнію $\mathrm{SiC}[9,10]$ і карбіду цирконію [9], парова газифікація коксу [12], термічна обробка металевих виробів [13], отримання хлориду цирконію $\mathrm{ZrCl}_{4}$ [14], отримання водню піролізом вуглеводнів [15], капсулювання кварцового піску піровуглецем [16], прожарювання зеленого нафтового коксу [17].

Всі конструкції печей з «низькотемпературним» ЕКШ можна розділити за напрямом електричного струму: поперек шару (в горизонтальній площині) і по осі шару (у вертикальній площині).

На рис. 1a, 2, 3 наведені конструкції печей 3 двома електродами $[17,18]$, які занурені в киплячий шар електропровідних частинок, що забезпечує нагрів шару при протіканні струму від одного електрода до іншого в горизонтальній площині. Аналогічна конструкція печі пропонується автором патенту [19]. Як варіант, можлива модифікація схеми на основі багатоелектродної системи [20] (рис. 4).

Інший варіант конструкції 3 поперечним рухом електричного струму - це печі 3 циліндричною робочою камерою, огорожа якої також $\epsilon$ електродом. Другий, центральний, електрод розташований по вертикальній осі. Отже, струм рухається в радіальному напрямку $[7,10,12,14$, 20]. Приклад такої печі для прямого відновлення оксидів заліза представлений на рис. 5 [7]. 


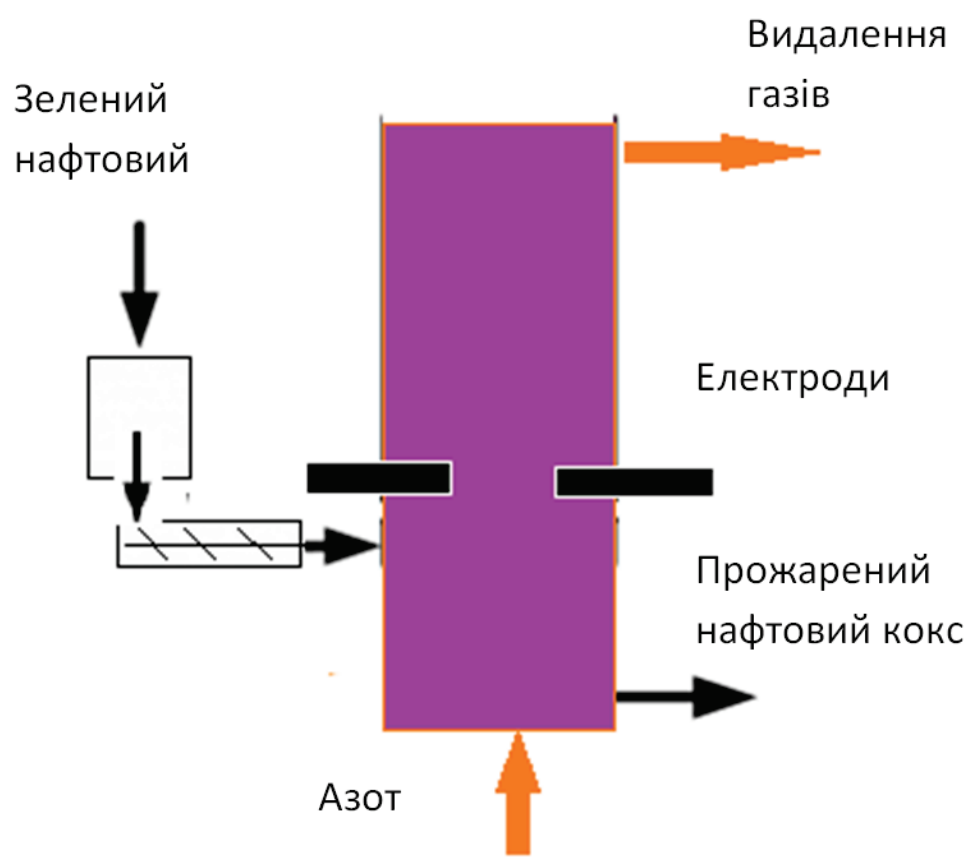

Рис. 2. Піч з ЕКШ для прожарювання нафтового коксу [17]

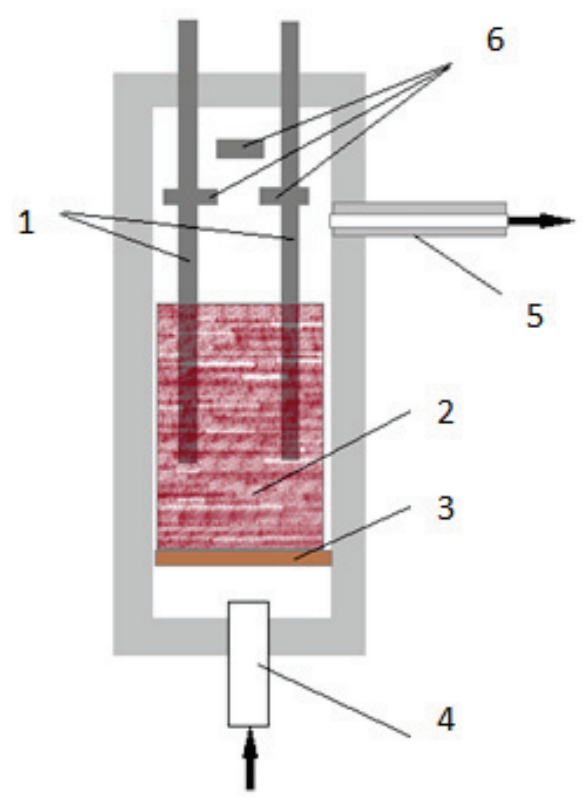

Рис. 3. Піч з електротермічним киплячим шаром для проведення каталітичних реакцій [18]: 1 - електроди; 2 - киплячий шар; 3 - газорозподільна решітка; 4, 5 - підведення і евакуація інертного газу; 6 - теплоізоляційні екрани 


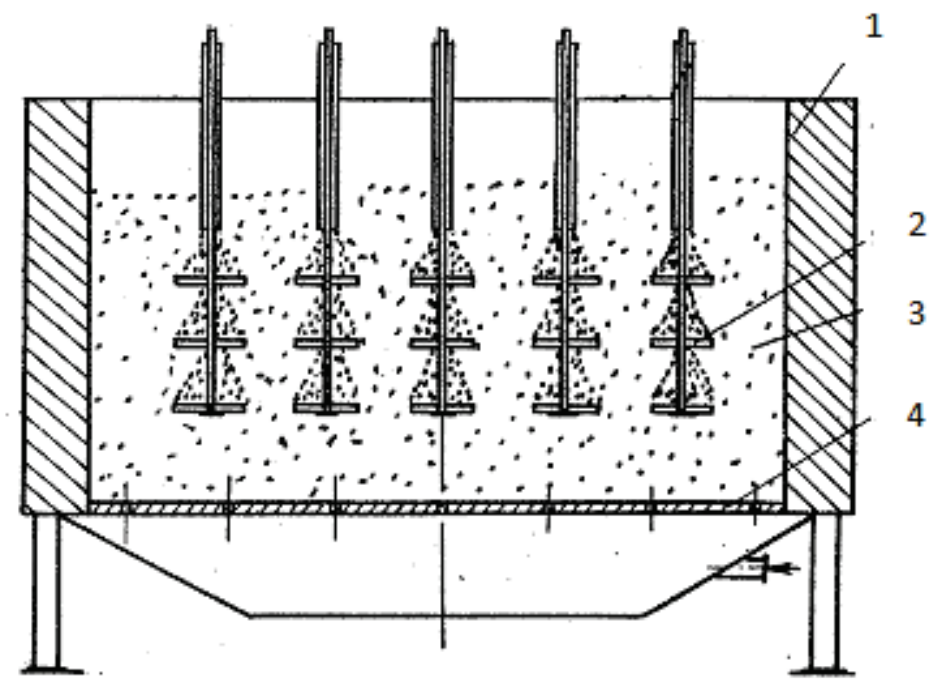

Рис. 4. Піч 3 електротермічним киплячим шаром [20]: 1 - футеровка печі; 2 - електроди; 3 - киплячий шар; 4 - газорозподільна решітка

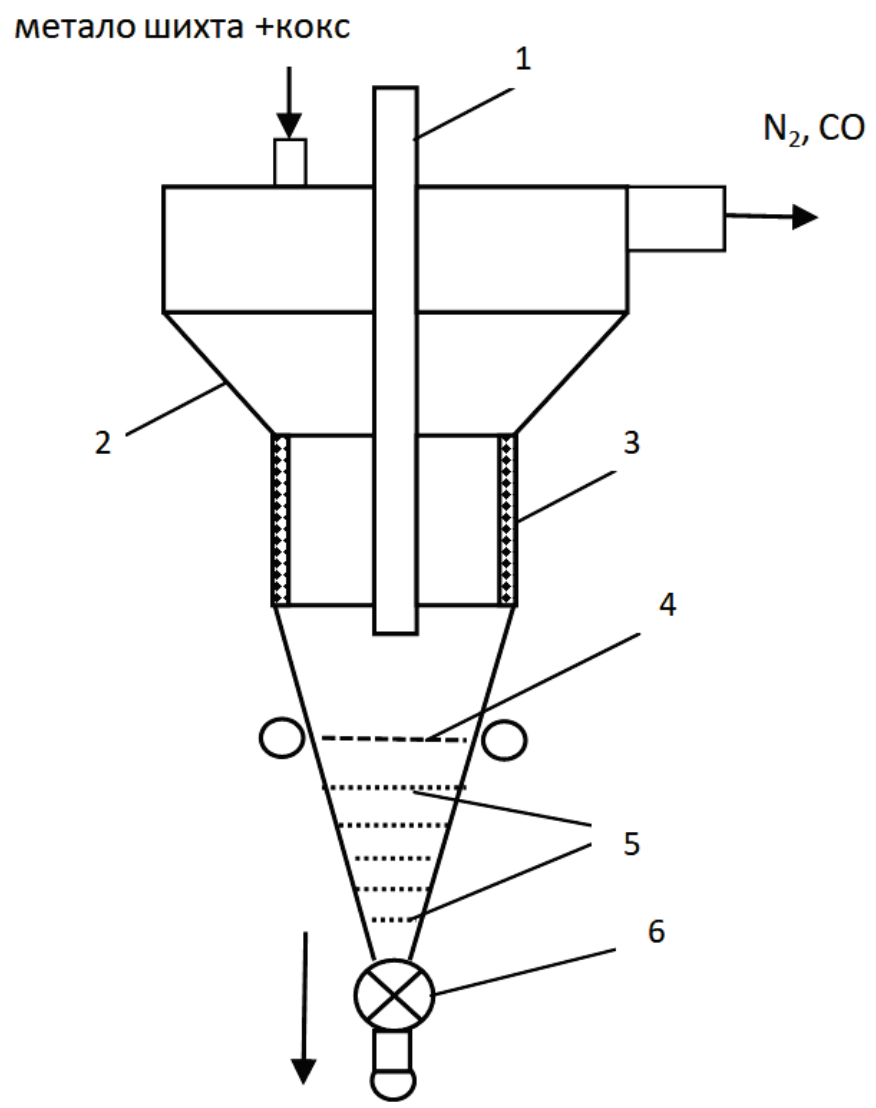

Рис. 5. Піч прямого відновлення оксидів заліза [7]: 1 - центральний електрод; 2 - футерований корпус печі; 3 - бічний електрод; 4 - подача інертного газу; 5 - подача реакційного газу; 6 - живильник вивантаження охолодженого матеріалу 
Відомі так само конструкції печей ЕКШ 3 вертикальним рухом струму [21 - 24]. В якості електродів використовують верхній електрод, нижня частина якого значно перекриває робочий простір печі і має розвинену форму поверхні (корону), та газорозподільну решітку (рис. 6, 7).

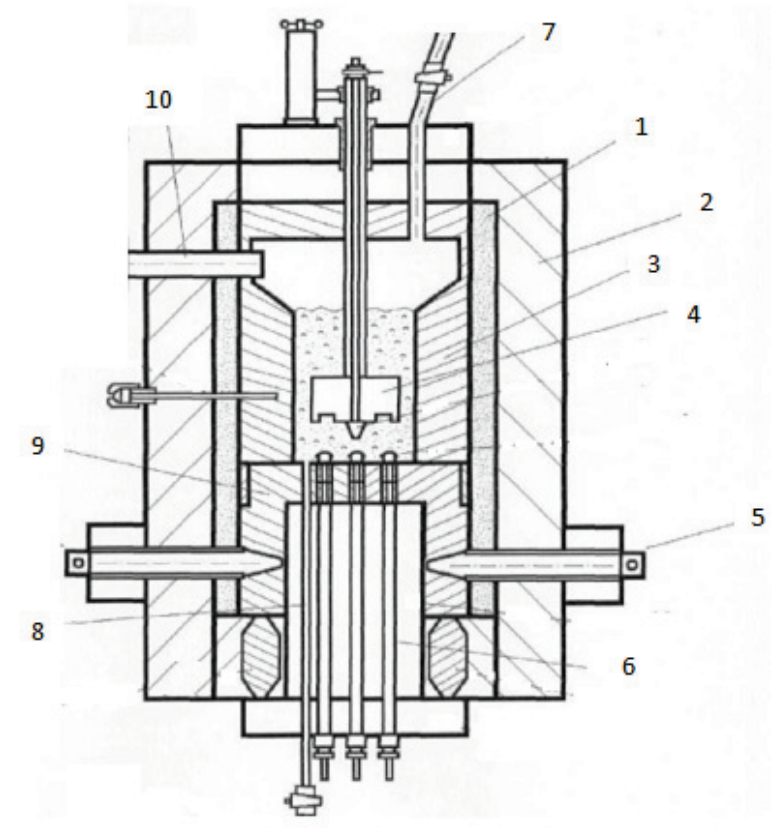

Рис. 6. Піч з електротермічним киплячим шаром для піролізу вуглеводнів [21]: 1 - теплова ізоляція; 2 - корпус печі; 3 - робоча камера 3 вогнетривкого матеріалу; 4 - верхній електрод; 5 - підведення струму; 6 - підведення вуглеводнів; 7 - подача вуглецевого матеріалу в шар; 8 - вузол вивантаження вуглецевого матеріалу з робочої камери; 9 - газорозподільна решітка - нижній електрод; 10 - видалення газу з робочої камери

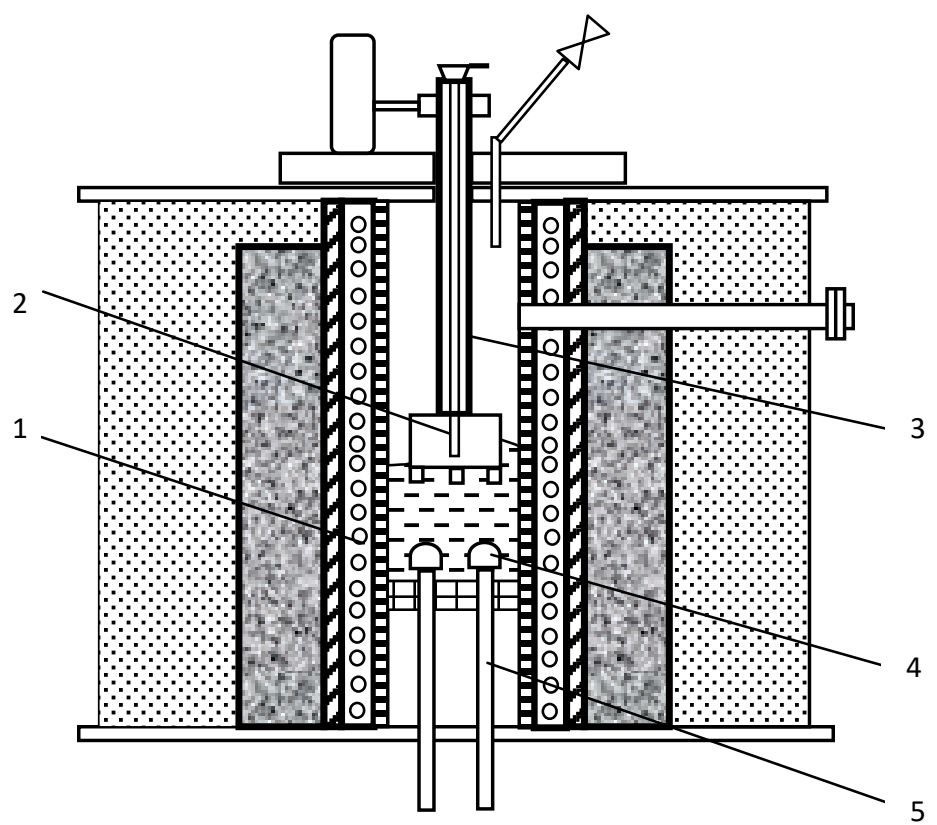

Рис. 7. Піч електротермічного киплячого шару для капсулювання кварцового піску піровуглецем [22]: 1 - охоронний зовнішній нагрівач; 2, 3 - верхній переміщуваний електрод; 4 - газорозподільна решітка нижній електрод; 5 - подача вуглеводневих газів 
Інакше виглядає конструкція печі з гратчастими електродами по висоті киплячого шару та вогнетривкою насадкою між ними [23] (рис. 8). Отже, має місце обмежений ЕКШ, де електроди підключені до різних фаз. Натомість в констру- кції печі [25] (рис. 9) реалізується підковоподібний рух струму. Електродами служать окремі елементи газорозподільної решітки, розділені електроізоляційними вставками у вигляді перегородок.

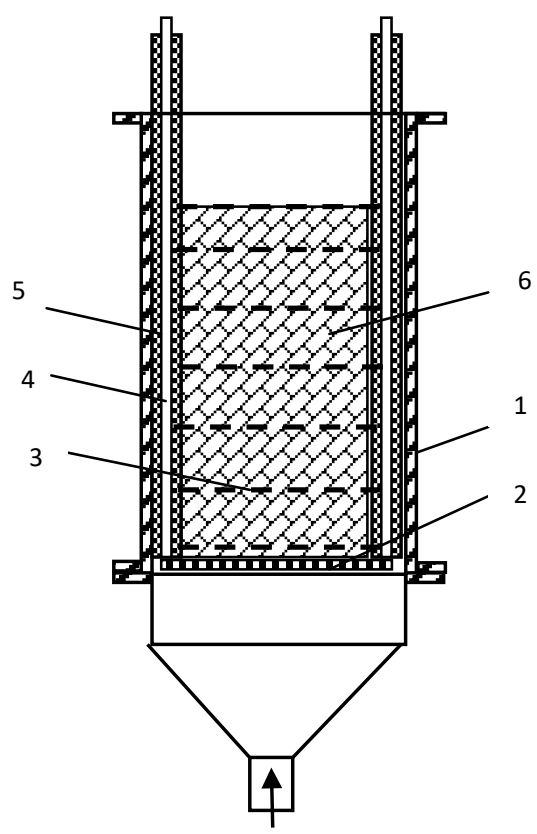

Рис. 8. Піч з обмеженим електротермічним шаром [23]: 1 - корпус; 2 - газорозподільна решітка; 3 - електроди; 4 - струмопровідні стрижні; 5 - електроізоляційні втулки; 6 - вогнетривка насадка

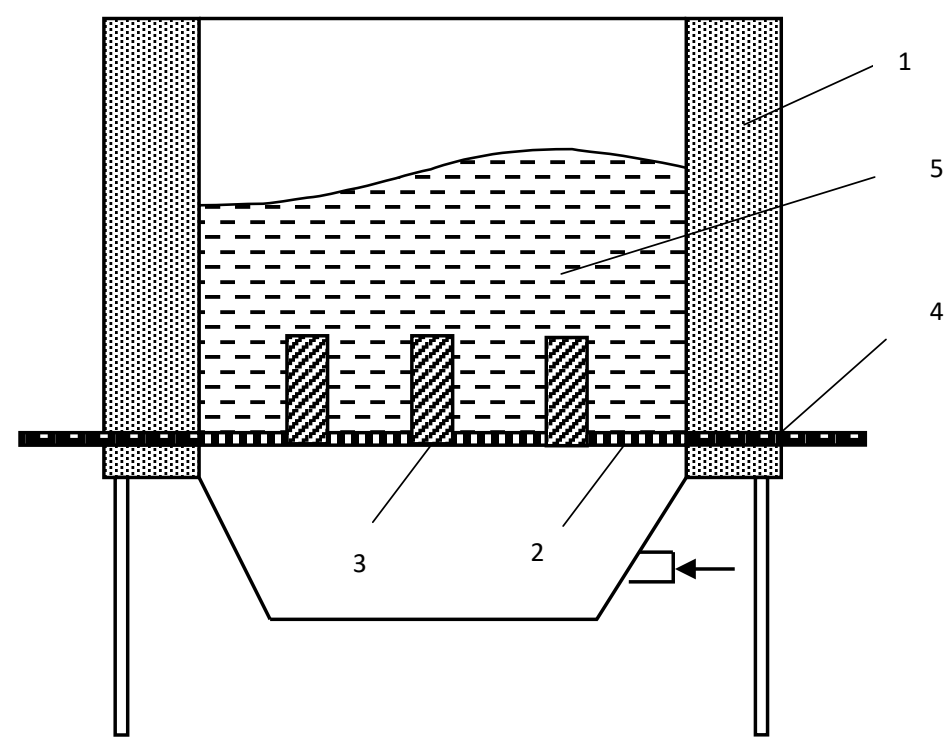

Рис. 9. Піч 3 електротермічним киплячим шаром [24]: 1 - футеровка печі; 2 - секція газорозподільної решітки - електрод; 3 - вертикальна перегородка 3 діелектрика; 4 - підведення струму; 5 - киплячий шар 


\section{«Високотемпературні» печі з ЕКШ}

«Високотемпературні» печі з ЕКШ мають конструкцію аналогічну до $[7,10,12,14,20]$ : 3 центральним електродом і електропровідною робочою камерою, футеровка якої $є$ другим електродом. Робоча камера виконується з графітових матеріалів, а у якості зріджуючого агенту використовуються інертні гази: аргон або азот. Такі печі зазвичай працюють в потоковому режимі 3 постійним завантаженням сировини та вивантаженням обробленого матеріалу [2528]. Типова конструкція високотемпературної печі представлена на рис. 10.

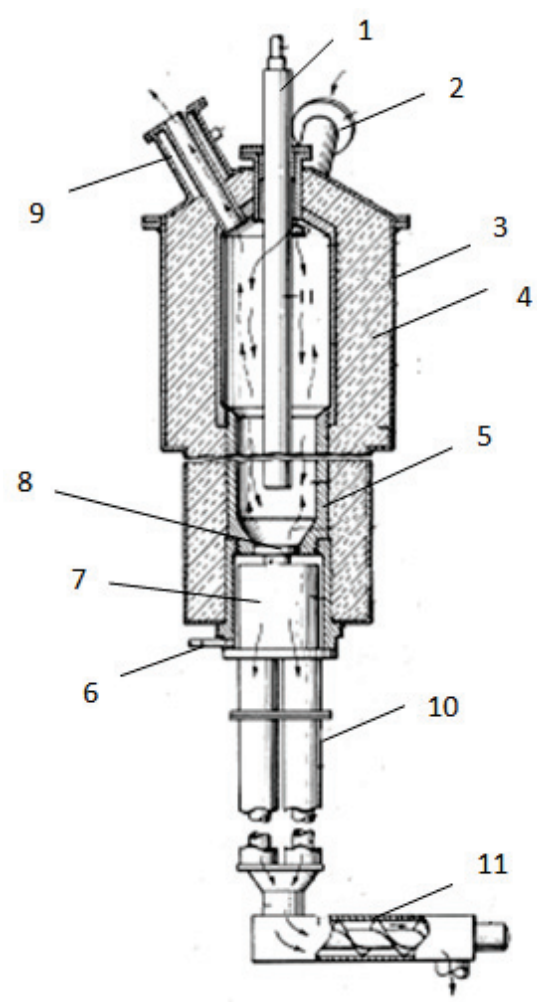

Рис. 10. Високотемпературна піч для обробки вуглецевого матеріалу в електротермічному киплячому шарі: 1 - центральний графітовий електрод; 2 - подача сирого матеріалу в піч; 3 - корпус печі; 4 - теплова ізоляція; 5 - графітове футерування робочої камери; 6 - подача інертного газу; 7 - розподільна камера готового матеріалу; 8 - газорозподільна решітка; 9 видалення відпрацьованих газів; 10 - холодильник готового матеріалу першого ступеня; 11 - шнековий холодильник готового матеріалу другого ступеня

Геометрія робочого простору високотемпературних печей ЕКШ

При розробці печей з ЕКШ необхідно вирішувати питання вибору конструктивних рішень наступних елементів: робочої камери, електродів, газорозподільчої решітки, організації видалення готового матеріалу і завантаження сировини, видалення газів та охолодження готового продукту.

Умовно робочу камеру (рис. 11) можна поділити на декілька елементів, які визначають ефективність роботи печі: робочий простір печі, де розташовується киплячий шар з висотою $\mathrm{H}_{\text {раб }}$ i діаметром $\mathrm{D}_{\text {раб; }}$; надшаровий сепараційні простір висотою $\mathrm{H}_{\text {нс }} \mathrm{i}$ діаметром $\mathrm{D}_{\text {нс }}$; ділянка від електрода діаметром $\mathrm{D}_{\mathrm{e}}$ до газорозподільної решітки $\mathrm{H}_{\mathrm{pe}}$.

Визначальними розмірами є розміри ЕКШ, в об'ємі якого відбувається тепловиділення: діаметр робочої зони $\mathrm{D}_{\text {раб̆}}$, діаметр електрода $\mathrm{D}_{\mathrm{e}}$, висота робочої зони $\mathrm{H}_{\text {раб. }}$. Вибір цих параметрів визначається чергою характеристик, які мають бути узгоджені між собою: 1) продуктивність печі; 2) електричний опір киплячого шару, який визначає напругу і силу струму на електродах; 3) допустима щільність струму в електроді; 4) допустима щільність струму на поверхні електрода по висоті робочої зони; 5) рівномірність тепловиділення і температурного поля в зазорі між центральним електродом і футеровкою печі; 6) стійкість центрального електрода. 


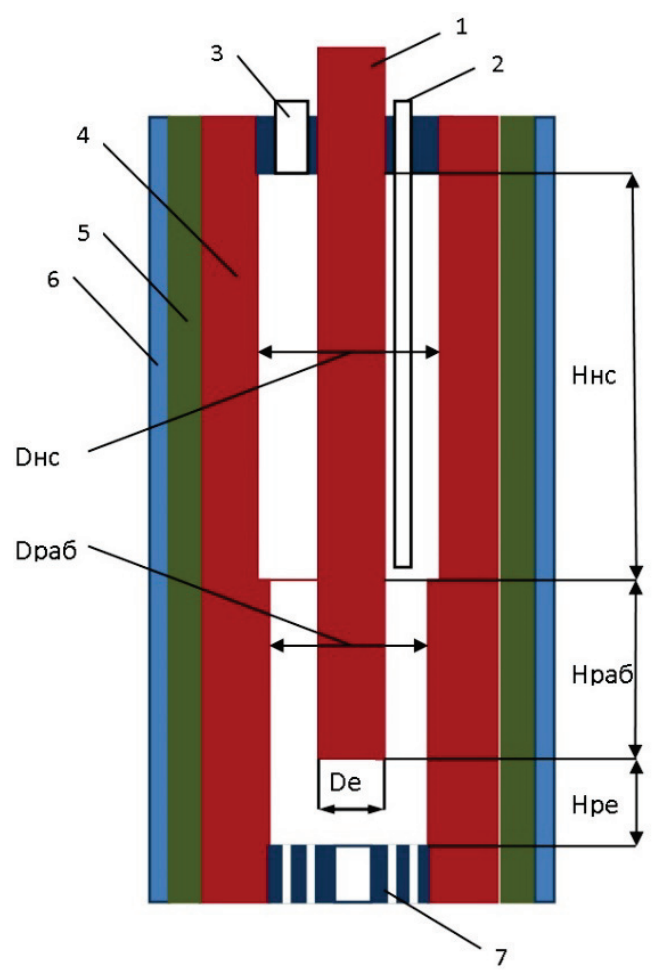

Рис. 11. Схема робочого простору печі 3 електротермічним киплячим шаром: 1 - центральний електрод; 2 - подача сировини в киплячий шар; 3 - видалення відпрацьованих газів; 4 - футеровка печі - електрод; 5 - теплова ізоляція; 6 - водоохолоджуваний корпус; 7 - газорозподільна решітка

На основі математичного моделювання процесів нагрівання вуглецевого матеріалу в електротермічному киплячому шарі [27, 29] висота робочої зони печі рекомендована як 2 - 5 діаметрів центрального електрода $\mathrm{H}_{\text {раб̆ }}=(2-5) \times \mathrm{D}_{\mathrm{e}}$. В [25] висота робочої зони визначається діаметром робочої зони і рекомендована як $\mathrm{H}_{\text {раб̆ }}=(0,5-2) \times \mathrm{D}_{\text {раб. }}$.

Для вибору діаметра робочої зони авторами [29] рекомендована залежність зв'язує основні конструктивні та технологічні параметри роботи печі:

$$
\frac{\mathrm{H}_{\text {раб }}}{\mathrm{D}_{\text {екв }}}=0,088 \cdot\left[\frac{\mathrm{N} \cdot \Omega}{\mathrm{U}^{2} \cdot \mathrm{V}^{1 / 3}} \cdot\left(\frac{\mathrm{D}_{\mathrm{e}}}{\mathrm{V}^{1 / 3}}\right)^{-0,65}\right]^{1,14},
$$

де $\mathrm{D}_{\text {екв }}$ - еквівалентний діаметр робочої зони [29], м; N - електрична потужність печі, кВт; $\Omega$ питомий електричний опір киплячого шару, Ом·м; $\mathrm{U}$ - напруга між центральним і футеровкою, В; $\mathrm{V}$ - об'єм киплячого шару робочої зони, $\mathrm{M}^{3}$.

В роботі [30] автори з метою підвищення надійності роботи печі і підвищення стійкості електрода рекомендують співвідношення діаметрів внутрішнього і зовнішнього електродів що становить $\mathrm{D}_{\mathrm{e}} / \mathrm{D}_{\text {раб }}=0,55 \ldots 0,66$. Саме таке співвідношення відповідає мінімальній напруженості електричного поля на поверхні центрального електрода та зменшує ймовірність утворення іскрових розрядів на його поверхні, характерних для електротермічного киплячого шару. Як відомо, саме іскрові розряди, в яких температура може досягати до $10000^{\circ} \mathrm{C}$, призводять до підвищеної ерозії анодів і необхідності їх періодичної заміни. Вирішення цієї проблеми можливе за рахунок екранування робочої поверхні анода насипним шаром матеріалу киплячого шару (рис. 4, 12) [22, 31]. Однак останній варіант може бути використаний тільки для «низькотемпературних» печей.

Вибір розмірів надшарового простору $\mathrm{H}_{\text {нс }} \mathrm{i}$ $\mathrm{D}_{\text {нс }}$ визначається можливостями сепарації частинок, які викидаються 3 киплячого шару і зниження механічного їх виносу з печі. Величина діаметра надшарового простору, як правило, більше діаметра робочого простору печей (рис. 5, 6, 10), що дозволяє знизити швидкість газу і зменшити винесення матеріалу з печі [9, $10,15,21,25,26,27]$. В [25] рекомендовано висоту надшарового простору вибирати на $50 \%$ більшою за висоту киплячого шару $\left(\mathrm{H}_{\text {раб }}+\mathrm{H}_{\text {ре }}\right)$. Однак в «низькотемпературних» печах діаметри 
робочої зони та надшарового простору можуть збігатися (рис. 7, 8, 9) [9, 18, 19, 22]. Висота надшарового простору повинна мінімізувати винесення матеріалу і за рекомендаціями [32] має становити не менше 1 м для частинок діаметром 100 - 200 мкм.

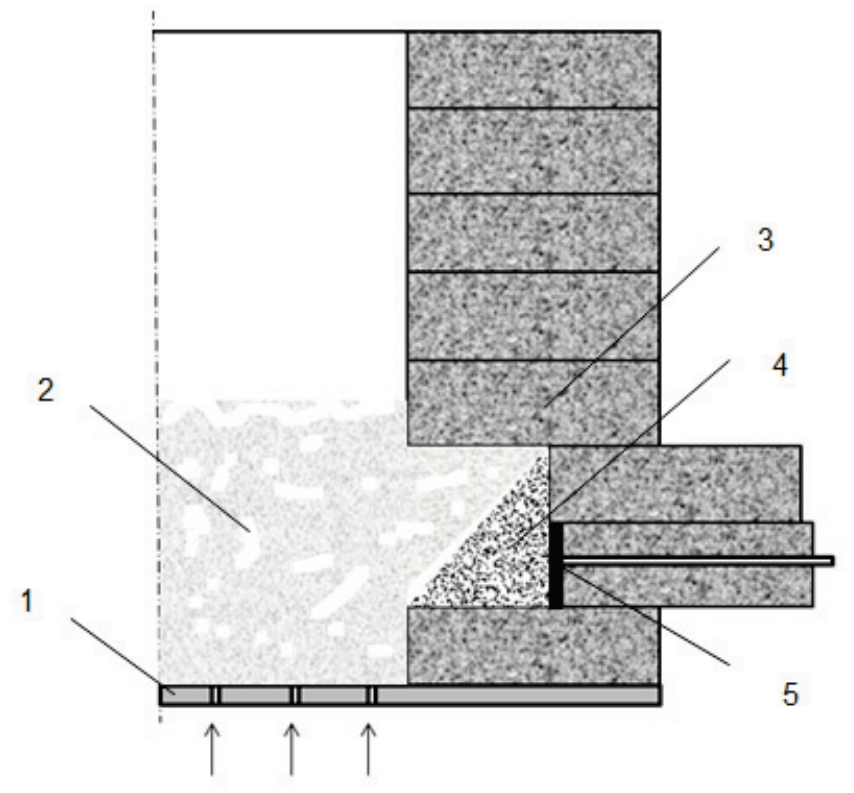

Рис. 12. Схема екранування анода матеріалом киплячого шару: 1 - газорозподільча решітка; 2 - електротермічний киплячий шар; 3 - футеровка печі 3 діелектричного матеріалу; 4 - захисний шар матеріалу; 5 - електрод

Вибір розмірів надшарового простору $\mathrm{H}_{\text {нс }} \mathrm{i}$ $\mathrm{D}_{\text {нс }}$ визначається можливостями сепарації частинок, які викидаються 3 киплячого шару і зниження механічного їх виносу 3 печі. Величина діаметра надшарового простору, як правило, більше діаметра робочого простору печей (рис. 5, 6, 10), що дозволяє знизити швидкість газу і зменшити винесення матеріалу з печі [9, $10,15,21,25,26,27]$. В [25] рекомендовано висоту надшарового простору вибирати на $50 \%$ більшою за висоту киплячого шару $\left(\mathrm{H}_{\text {раб }}+\mathrm{H}_{\mathrm{pe}}\right)$. Однак в «низькотемпературних» печах діаметри робочої зони та надшарового простору можуть збігатися (рис. 7, 8, 9) [9, 18, 19, 22]. Висота надшарового простору повинна мінімізувати винесення матеріалу і за рекомендаціями [32] має становити не менше 1 м для частинок діаметром 100 - 200 мкм.

Одним 3 важливих розмірів робочого простору печі є відстань від газорозподільної решітки до початку робочої зони печі (рис. 10). Величина цієї відстані повинна забезпечувати основне тепловиділення в радіальному зазорі між електродами і мінімізувати виток струму на решітку, що дозволяє управляти процесом за рахунок зміни глибини занурення центрального електрода. Автори [27] рекомендують величину $\mathrm{H}_{\text {pe }}$ не менше одного діаметра центрального електрода, що гарантує виділення не менше 90 \% теплової енергії в зазорі між футеровкою та центральним електродом.

\section{Газорозподільні пристрої високотемпе- ратурних печей ЕКШ}

Конструкція газорозподільної решітки має забезпечувати рівномірний розподіл інертного газу у робочому просторі печі, інтенсивне перемішування матеріалу. Головна мета - забезпечення рівномірного температурного поля та відсутність застійних зон, в яких можливе скупчення необробленого матеріалу. Крім цього, решітка, як правило, має канал для вивантаження обробленого матеріалу з робочої камери. У практиці використовуються два види решіток плоскі 3 рівномірним [9, 15 - 16, 18, 20 - 23] (pic. 3, 4, 6 9) i нерівномірним [25] (рис. 10) розподілом отворів для проходу газу, а також конусні решітки, які, у свою чергу, спрямовують рух матеріалу до отвору вивантаження [7, 10, 24, 26]. Решітки можуть бути провального [18, 19, 23, 25, 27] i непровального [7, 15 - 16, $21-22,24,26]$ типів, в тому числі і ковпачкові (рис. 6,7 ). 
Конусна провальна решітка (рис. 13) [10] 3 рівномірним розподілом отворів для подачі газу та центральним розвантажувальним каналом має кут $5-10^{\circ}$, який забезпечує сходження матеріалу до центрального отвору для вивантаження.

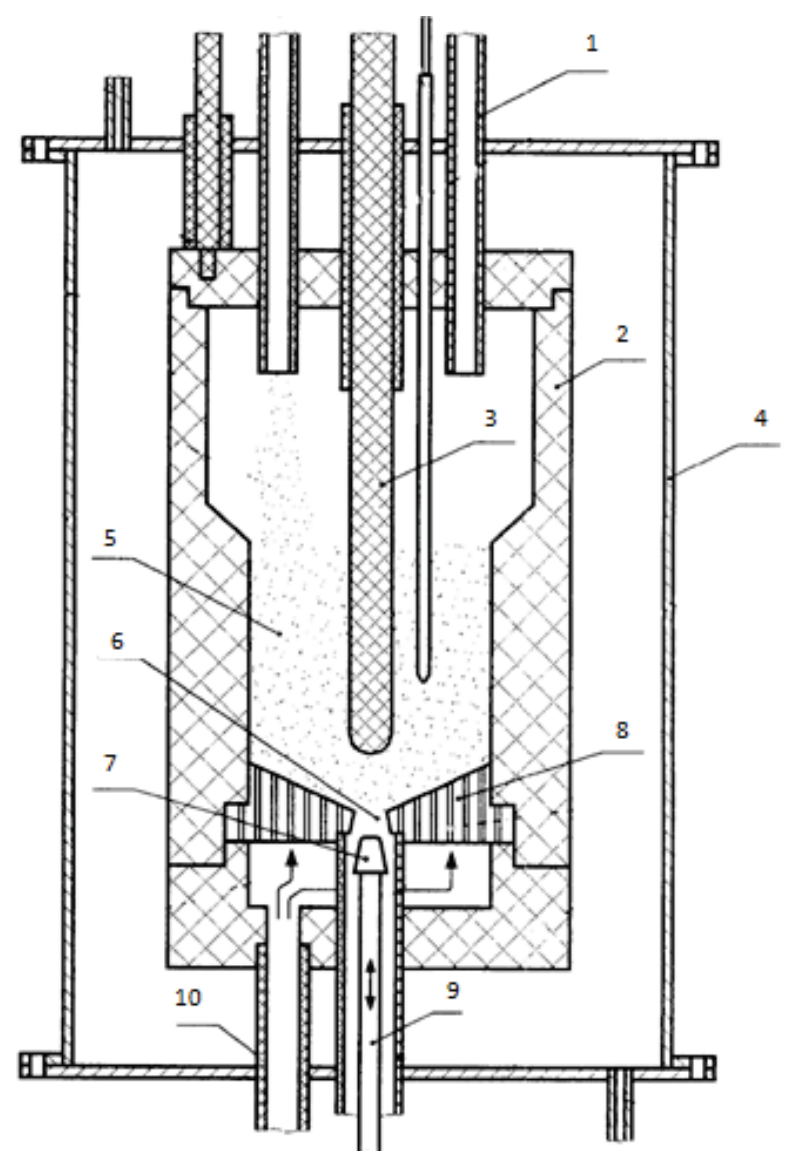

Рис. 13. Схема печі з електротермічним киплячим шаром для отримання карбіду кремнію [10]: 1 - подача сировини; 2 - графітова футеровка; 3 центральний електрод; 4 - корпус печі; 5 - електротермічний киплячий шар; 6 - розвантажувальний отвір; 7, 9- конусна штанга для регулювання розвантаження готового матеріалу; 8 - газорозподільча решітка; 10 - подача інертного газу

Конструкція непровальної решітки авторів [24] являє собою ступінчасту конструкцію 3 графітових кілець (рис. 14), між якими організована подача газу в шар, при цьому кільця електрично розв'язані між собою. Це дозволяє керувати напругою, яка подається на них, i таким чином управляти розподілом джерел теплоти в вертикальному киплячому шарі. При цьому можлива організація подачі газу тангенціально (рис. 15), що забезпечує обертальний pyx шару і забезпечує поліпшення перемішування матеріалу.

Заслуговує на увагу технічне рішення з використання конусних решіток 3 нерівномірним розподілом отворів по висоті $[7,25]$ (рис. 5,16 ).
Подача газу здійснюється в верхньої частини конусної решітки через один ряд сопел. В [25] центральний кут конусної решітки рекомендується вибирати в діапазоні $40-60^{\circ}$, а висота розташування сопел становить $0,50-0,75$ висоти конуса. Таке рішення забезпечує роботу киплячого шару із заданою циркуляцією матеріалу в робочій камері аналогічно роботі апаратів 3 фонтануючим шаром: підйом матеріалу у центрального електрода і його сходження у бічної футеровки. Відповідна схема забезпечує повну обробку всього матеріалу і гарантоване його перемішування.

Аналогічно конструкції [24] автори печі [25] передбачили можливість тангенціального 
введення газових струменів в робочий простір печі з метою забезпечення вихрового руху шару (рис. 17). При цьому сопла утворюють кут до дотичній рівний $\beta=10-20^{\circ}$, а сумарна площа сопел становить $0,15-0,50$ площі перерізу робочої зони печі з діаметром $\mathrm{D}_{\text {раб. }}$

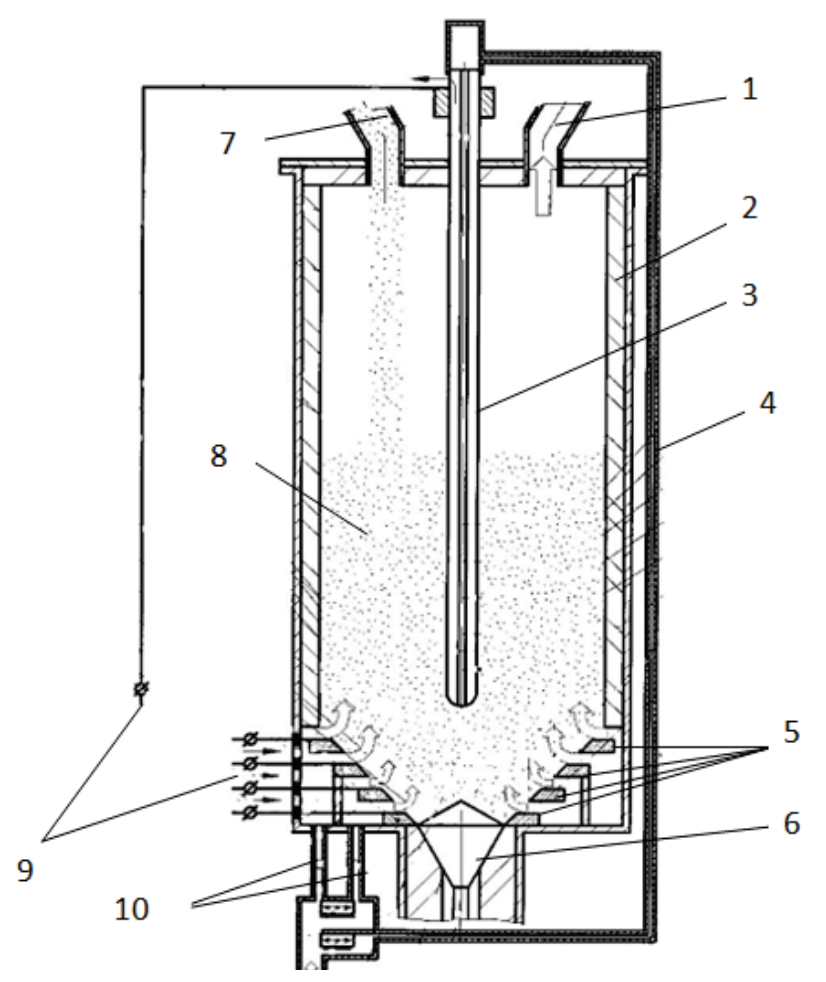

Рис. 14. Піч з електротермічним киплячим шаром [24]: 1 - патрубок видалення відпрацьованих газів; 2 - футерований корпус печі; 3 - центральний електрод; 4 - подача газу до центрального електроду; 5 - графітові кільця, що утворюють непровальну решітку; 6 - канал для видалення обробленого матеріалу; 7 - патрубок завантаження сировини; 8 - електротермічний киплячий шар; 9 - підведення електроенергії; 10 - подача інертного газу

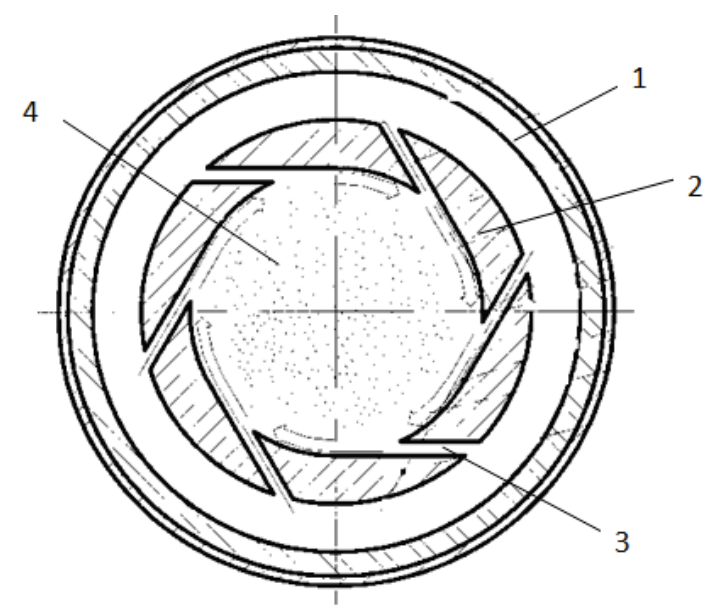

Рис. 15 Схема газорозподільної решітки 3 тангенціальним підведенням інертного газу [24]: 1 - футерований корпус; 2 - графітове кільце; 3 тангенціальний канал для підведення інертного газу; 4 - електротермічний киплячий шар 


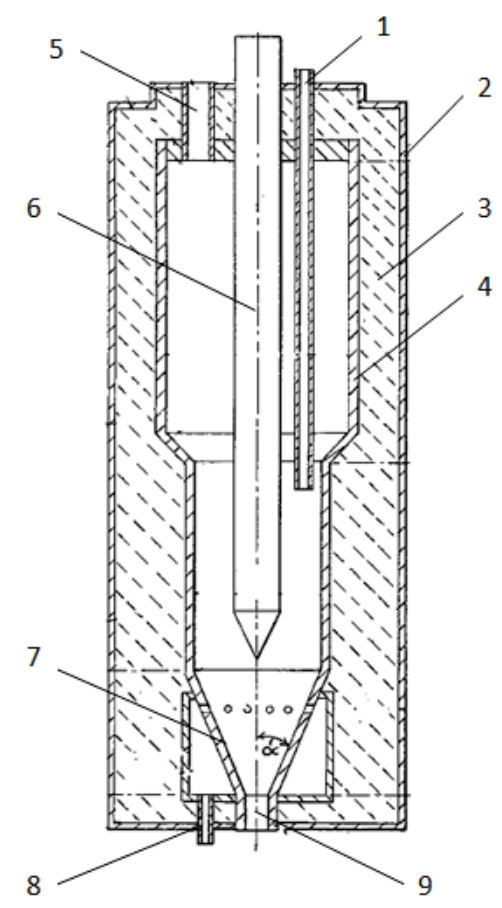

Рис. 16. Піч з електротермічним киплячим шаром для обробки вуглецевого матеріалу [25]: 1 - патрубок для завантаження сировини; 2 - корпус печі; 3 - теплова ізоляція; 4 - графітова футерування - електрод; 5 - патрубок відводу відпрацьованих газів; 6 - центральний електрод; 7 - конусна газорозподільна решітка; 8 - підведення інертного газу; 9 - патрубок вивантаження готової продукції

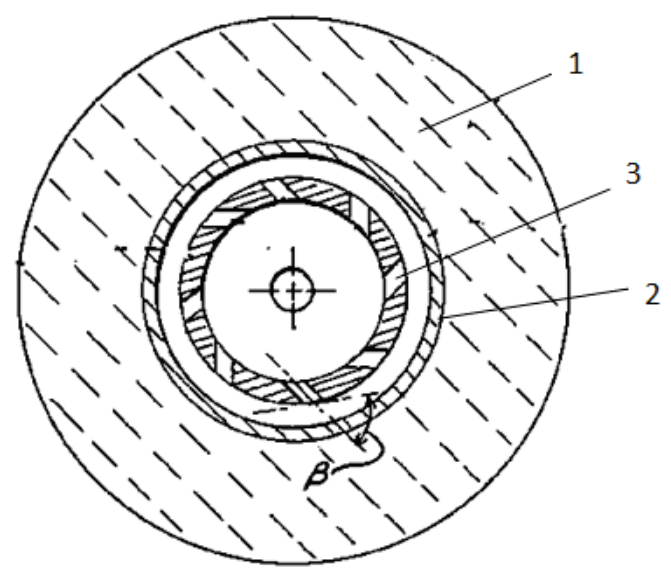

Рис. 17. Схема тангенціального підведення газу через конусну решітку [25]: 1 - теплова ізоляція; 2 - газорозподільча камера; 3 - конусна газорозподільча решітка 3 соплами для подачі інертного газу

Цікавим є технічне рішення [33] щодо подачі інертного газу в киплячий шар, характерне для фурменої продувки розплавів в металургійних агрегатах (рис. 18). Розподільча решітка поєднана $з$ центральним електродом, через який подається інертний газ і розподіляється в шарі через сопла у нижній частині електрода. Такий варіант спрощує конструкцію нижньої частини печі і дозволяє організувати циркуляційний рух матеріалу в робочій зоні аналогічно до [25], а так само дозволяє виключити операцію заміни решітки при виході ії з ладу, яка вимагає повного охолодження печі. Крім цього інертний газ охолоджує електрод і нагрівається перед подачею в шар.

Аналогічне рішення використано і в роботі [30] (рис. 19), де запропоновано розігрівати реагент в каналах центрального електрода і одно- 
часно підвищити його стійкість. Відмінність від робочий простір через кільцеву газорозподільну [33] полягає в тому, що розігрітий газ подають у решітку.

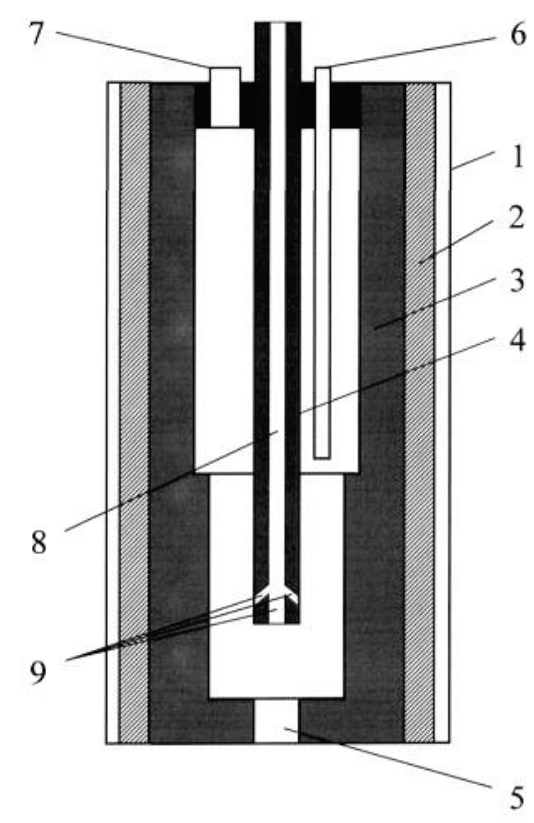

Рис. 18. Електротермічна піч $з$ киплячим шаром для високотемпературної обробки вуглецевих матеріалів [33]: 1 - корпус печі; 2 - теплова ізоляція; 3 - графітова футеровка; 4 - центральний електрод; 5 - випускна труба для обробленого матеріалу; 6 - труба для завантаження сировини; 7 - газохід для видалення газів, що відходять; 8 - вертикальний канал для подачі інертного газу; 9 - сопла для подачі інертного газу в шар

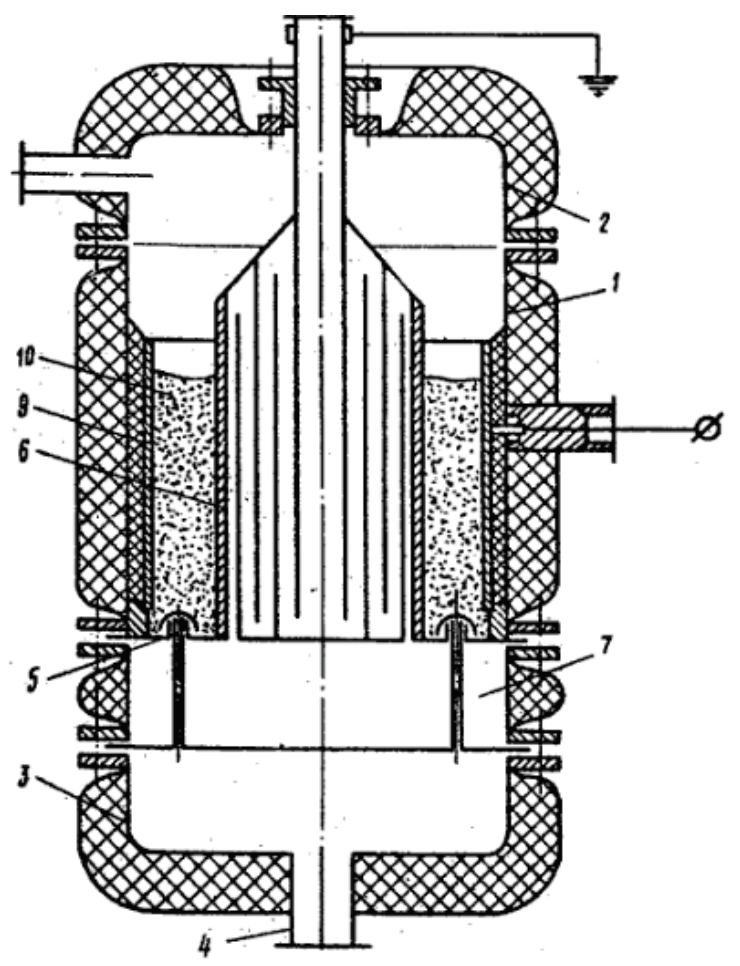

Рис. 19. Схема реактора синтезу з ЕКШ [30]: 1 - корпус; 2 - кришка; 3 - днище; 4 патрубок подачі леткого компонента; 5 - газорозподільча решітка; 6 - центральний електрод; 7 - під решітчастий простір; 8 - патрубок для подачі важколеткого компонента; 9 - зовнішній електрод; 10 - реакційний простір 
Попередній розігрів інертного газу перед подачею в ЕКШ дозволяє вирішити кілька завдань одночасно: зменшити витрату інертного газу, знизити теплові втрати, пов'язані 3 його нагріванням і забезпечити підтримку рівномірної швидкості газу по висоті печі, що забезпечує підтримку певного гідравлічного режиму киплячого шару. Особливо це важливо для високотемпературних печей. Подібне рішення авторів [25] полягає в організації подачі інертного газу через кільцевий канал, в якому відбувається попереднє нагрівання газу (рис. 20).

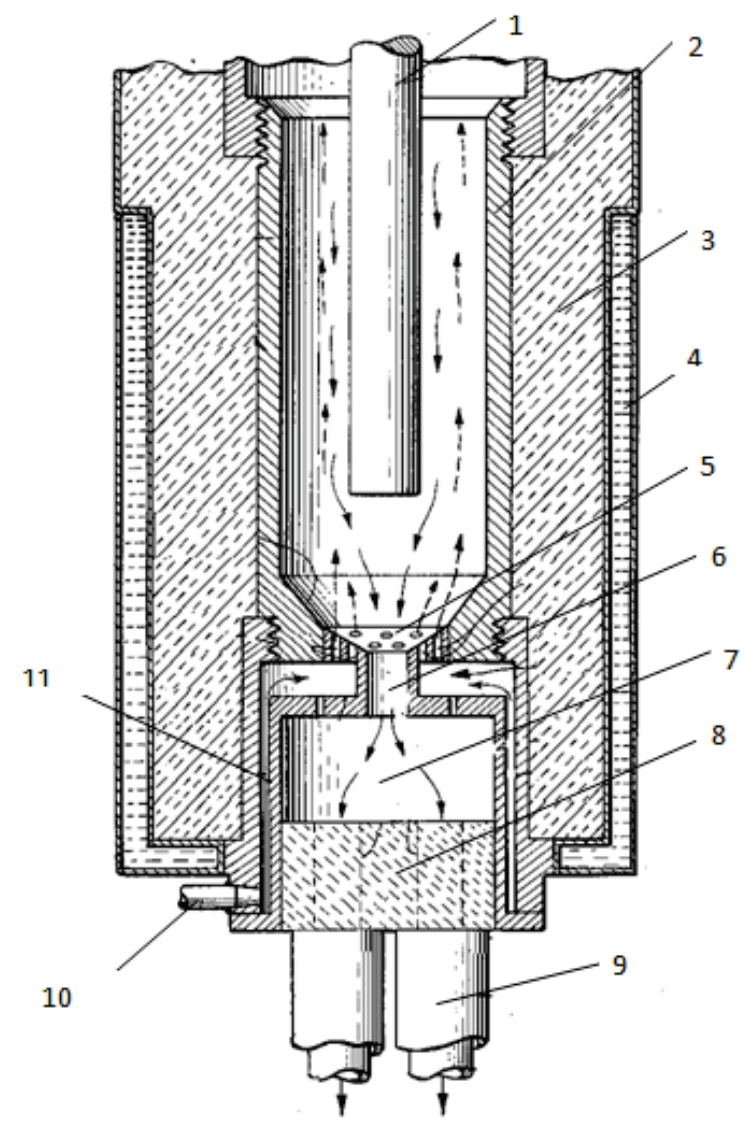

Рис. 20. Високотемпературна піч для обробки вуглецевого матеріалу в ЕКШ [25]: 1 - центральний графітовий електрод; 2 - графітова футерування робочої камери; 3 - теплова ізоляція; 4 - водоохолоджуваний корпус печі; 5 - газорозподільна решітка; 6 - канал для вивантаження готового продукту; 7 - розподільна камера готового матеріалу; 9 - холодильник готового матеріалу першої ступені; 10 - подача інертного газу; 11 - кільцевий канал для подачі інертного газу

\section{Організація руху матеріалу у печах ЕКШ}

Більшість 3 розглянутих конструкцій печей - агрегати безперервної дії, в яких реалізований потоковий процес обробки матеріалу [7, 9, 10, 16 - 17, 21 - 28, 33], що вимагає постійного завантаження сировини і вивантаження готового продукту. Подача сировини в піч традиційно здійснюється через окремий канал у верхній кришці. При цьому матеріал потрапляє в робочий простір під дією сили тяжіння [7, 9, 10 , 21, 22, 24, 25] (рис. 5, 6, 7, 10, 12, 11, 13, 15). Водночас у верхній частині організовано відведення відпрацьованих газів.

Таким чином частки і газ рухаються в про- титоці, що може викликати винесення необроблених частинок матеріалу разом 3 газами. Для усунення цього недоліку авторами [25, 27, 33] запропонована подача сировини через трубу безпосередньо в киплячий шар або на його поверхню (ріс. 16, 18). В роботі [20] (рис. 4) подачу сировини в киплячий шар здійснюють через електроди, таким чином, спрощуючи конструкцію печі.

У більшості конструкцій печей безперервної дії вивантаження здійснюється через канал у газорозподільчій решітці, в якому він рухається в щільному шарі за рахунок сили тяжіння. Після вивантаження обробленого матеріалу з робочої 
камери печі він спрямовується в холодильник, при цьому утворюється щільний шар матеріалу, який виконує функцію гідравлічного затвору та перешкоджає руху газів 3 робочого простору через холодильник (рис. 20).

В [25] передбачена розподільна камера, в якій відбувається усереднення матеріалу, роз- поділ його між холодильниками, а так само витримка при високих температурах, що забезпечує обробку частинок які транзитом пройшли через киплячий шар. Рух матеріалу в холодильнику визначається або живильниками (рис. 10) або затворами різних типів [9] (рис. 21).

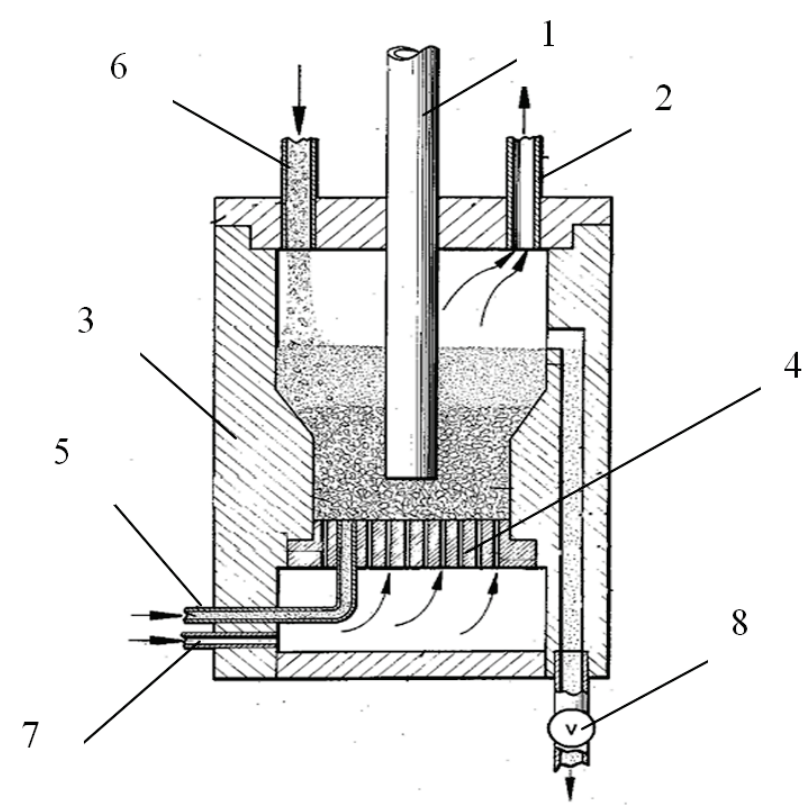

Рис. 21. Електротермічна піч для виробництва карбідів [9]: 1 - центральний електрод; 2 - патрубок для видалення відпрацьованих газів; 3 - футеровка печі; 4 - газорозподільна решітка; 5, 6 - подача сировини; 7 - подача інертного газу; 8 - затвор розвантаження готової продукції

\section{Висновки}

На основі аналізу конструкцій печей з електротермічним киплячим шаром запропоновано їх класифікація на низькотемпературні $1000-$ $1600{ }^{\circ} \mathrm{C}$ та високотемпературні - до $3000{ }^{\circ} \mathrm{C}$. Переважна більшість технологічних процесів відноситься саме до низькотемпературних, зокрема, пряме відновлення заліза; отримання карбідів титану, кремнію та цирконію; парова газифікація коксу; термічна обробка металевих виробів; синтез хлориду цирконію; отримання водню піролізом вуглеводнів; капсулювання кварцового піску піровуглецем; прожарювання зеленого нафтового коксу.

Натомість високотемпературні печі можуть застосовуватись здебільшого для вузьких технологічних задач, таких як графітизація та термічне рафінування вуглецевих матеріалів.

За напрямом руху електричного струму печі поділяються на установки: 3 горизонтальним рухом (поперек шару) та вертикальним рухом (у вертикальній площині). У високотемпературних печах реалізовано переважно горизонтальний рух струму.

Узагальнено рекомендації щодо вибору розмірів робочої камери печей з електротермічним киплячим шаром. В тому числі діаметр і висота робочої зони, розміри надшарового простору, відстань між електродом і газорозподільчою решіткою.

В роботі наведено аналіз особливостей конструкції газорозподільчих решіток 3 провальними й непровальними пристроями, а також підведення газу на основі заглиблених фурм.

Визначено основні варіанти організації поточного процесу з безперервним завантаженням сировини та вивантаженням обробленого матеріалу. Основною особливістю цих вузлів є можливість подачі сировини безпосередньо у киплячий шар, а система вивантаження повинна вирішувати крім основного завдання функцію 
гідравлічного затвору та перешкоджає руху газів з робочого простору.

\section{Бібліографічний список}

1. Gupta C., Sathiyamoorthy D. Fluid bed technology in materials processing. Boca Raton, Fla. : CRC Press, 1999. 528 p.

2. Забродський С. С. Високотемпературні установки з псевдозрідженим шаром. М. : Енергія, $1971.328 \mathrm{c.}$

3. Баскаков А. П. Скоростной безокислительный нагрев и термическая обработка в кипящем слое. М.: Металлургия, 1968. 223 с.

4. Гущин С. Н., Майзель С. Г., Матюхин В. И., Гольцев В. А. Теплотехнические расчеты печей глиноземного производства. Екатеринбург : УГТУ, 2000. 229 с.

5. Волочко А. Т., Шипко А. А., Демин Н. И., Будзинская А. В. Мониторинг применения огнеупорных материалов на предприятиях республики Беларусь. Литье и металлургия. 2011. № 4. С. 53-59.

6. Кащеев И. Д. Огнеупоры для промышленных агрегатов и топок : справочное издание, Кн. 1. М. : Интермет Инжинииринг, 2000. 663 с.

7. Process and apparatus for the direct reduction of Irion oxides in an electrothermal fluidized bed and resultant product: pat. WO/2003/080874 US : B01J 2208/00398/. № PCT/US2003/008347; fil. 19.03.2003; pub. 02.10.2003. 5 p.

8. Tuot James. Prodaction of TiC in an electrothermal fluidized bed. Department of Chemical Engineering: McGi11 University, 1976. 680 p.

9. Method for the continuous production of carbides : pat. 4543240 US : C01B31/36/. № 06/691076; fil. 01.14.1985; pub. 09.24.1985. $4 \mathrm{p}$.

10. Способ и установка для получения карбида кремния : пат. 2015/EA/0077 ВY : C01B 31/36. Заявка № 027539; подан. 2015.05.07; опубл. 2017.08.31. Бюл. № 8.4 p.

11. Алексеева Т. И., Галевский Г. В., Руднева В. В., Галевский С. Г Технологические решения в производстве карбида циркония: анализ, оценка состояния и перспектив. Научнотехнические ведомости СПбГПУ. 2017. № 23(1). C. 256-270.

12. Knowlton T. M., Pulsifer A. H., Wheelock T. D. Coal char gasification in an electrofluid reactor. Ind. Eng. Chem. Process Des. Dev. 1969. № 8(4). P. 539.
13. Electric direct heating method metallic pieces : pat. 306034 US : H05B3/60/. № US3060304A; fil. 19.10.1959; pub. 23.10.1962. $3 \mathrm{p}$.

14. Manieh A., Scott D. S., Spink D. R. Electrothermal Fluidized Bed Chlorination of Zircon. The Canadian Journal of Chemical Engineering. 1974. № 52. P. 507-514.

15. Кажан А. П., Богомолов В. А., Ховавко А. И., Бондаренко Б. И., Симейко К. В. Исследование процесса получения водорода пиролизом углеводородов в аппарате с электротермическим псевдоожиженным слоем. Энерготехнологии и ресурсосбережение. 2012. № 2. С. 27-31.

16. Богомолов В. А., Кажан А. П., Бондаренко Б. И., Ховавко А. И., Симейко К. В. Капсулирование кварцевого песка пироуглеродом в электротермическом псевдоожиженном слое. Энерготехнологии и ресурсосбережение. 2013. № 5. C. 33-36.

17. Kozlov A., Chudnovsky Ya., Khinkis M., Yuan H., Mark Zak M. Advanced Green Petroleum Coke Calcination in an Electrothermal Fluidized Bed Reactor. EPD Congress. 204, 17 January 2014. P. 1-8.

18. Electrothermic fluidzed bed process : pat. 3499947A US : B01J8/42/. № US3499947A; fil. 05.08.1968; pub. 03.10.1970. 4 p.

19. Electrothermic fluidzed bed apparatus: pat. US3006838A : B01J8/42/. № US759769A; fil. 09.08.1958; pub. 31.10.1961. 4 p.

20. Реактор с электротермическим кипящим слоем : пат. SU 1223989A : B01J 8/18/. Заявка № 027539; подан. 1984.07.10; опубл. 1986.15.04. Бюл. № 14.4 p.

21. Реактор для піролізу газоподібних вуглеводнів: пат. UA 83147 : C 10 G 9/32/. Заявка № u 2013 03318; подан. 2013.18.03; опубл. 2013.27.08. Бюл. № 16.4 p.

22. Реактор для високотемпературних процесів у псевдозрідженому шарі : пат. UA 117157: В01J 8/18/. Заявка № а 2013 06499; подан. 2015.01.07; опубл. 2017.26.06. Бюл. № 12. $4 \mathrm{p}$.

23. Аппарат для непосредственного нагрева псевдоожиженного слоя : пат. SU 181211: 21H, 15/02/. Заявка № 181211; подан. 1965.07.04; опубл. 1966.15.04. Бюл. № 9. 2 с.

24. Способ электротермической переработки дисперсного материала в псевдоожиженном слое и устройство для его осуществления: пат. $2663425 \mathrm{RU}: \mathrm{B} 01 \mathrm{~J} 8 / 18 /$ З Заявка № 0002663425; опубл. 2018.06.08. 6 p. 
25. Method for heat treating carbonaceous material in a fluidzed bed: pat. 4160813 US : C10B19/00/. № US59211875A; fil. 21.07.1978; pub. 10.06.1979. $4 \mathrm{p}$.

26. Method and apparatus for heat treatment of particulates in an electrothermal fluidized bed furnace and resultant products : pat. US20050062205A1: F27B15/10/. № US10/666,614; fil. 18.09.2003; pub. 24.03.2005. $4 \mathrm{p}$.

27. Реактор для високотемпературних процесів у псевдозрідженому шарі : пат. UA 108964 : F27B 15/00/. Заявка № u 2015 00065; подан. 2015.01.07; опубл. 2016.10.08. Бюл. № 15. $4 \mathrm{c}$.

28. Електротермічна піч псевдозрідженого шару: пат. UA 107972: F27B 15/00 /. Заявка № u 2016 00086; подан. 2016.04.01; опубл. 2016.24.06. Бюл. № $12-4$ с.

29. Федоров, С. С., Губинский, М. В., Форись, С. Н. Выбор размеров рабочего пространства электротермических печей кипящего слоя для переработки углеродных материалов. $\mathrm{Me-}$ таллургическая и горнорудная промышленность. 2014. № 4. С. 87-90.

30. Реактор с электротермическим кипящим слоем : пат. SU 1003878 : B01J 8/18/. Заявка № 1003878; подан. 1981.02.04; опубл. 1983.15.03. Бюл. № 10. 2 с.

31. Установка с электротермическим кипящим слоем : пат. SU 423861: F27D 11/10/. Заявка № 423861; подан. 1971.03.05; опубл. 1974.15.04. Бюл. № 14. 2 с.

32. Расчеты аппаратов кипящего слоя : справочник / Под ред. И. П. Мухленова, Б. С. Сажина, В. Ф. Фролова. Л. : Химия, 1986. 352 с.

\section{References}

1. Gupta, C. K., Sathiyamoorthy, D. (1999). Fluid bed technology in materials processing. Boca Raton, Fla.: CRC Press

2. Zabrodskii, S. S. (1971). Vysokotemperaturnyie ustanovki s psovdoozhizhinin sloem. Moskva: Energiya

3. Baskakov, A. P. (1968). Skorostnoy bezokislitelnyi nagrev I termicheskaya obrabotka d kipyasghem sloe. Moskva : Metalurgiya

4. Guschin, S. N., Maizel, S. G., Matyuhin, V. I., \& Goltsev, V. A. (2000). Teplotechnicheskiye raschety pechey glinozemnogo proizvodstva. Ekaterinburg: UGTU

5. Volochko, A. T., Shipko, A. A., Demin,
N. I., \& Budzinskaya, A. V. (2011). Monitoring primeneniya ogneupornyh materialov na predpriyatiyah respubliki Belarus. Litie i metalurgiya, (4), 53-59

6. Kascheev, I. D. (2000). Ogneupory dlya promyshlennyh agregatov $i$ topok: Spravochnoye izdaniye (Vol. 1). Moskva: Intermet Inginiring

7. Goldberger, W. M., \& Zak, M. S. (2003). Process and apparatus for the direct reduction of Irion oxides in an electrothermal fluidized bed and resultant product. Pat. WO/2003/080874 US : B01J 2208/00398/; SUPERIOR GRAPHITE CO.№ PCT/US2003/008347

8. Tuot, J. (1976). Prodaction of TiC in an electrothermal fluidized bed Departrment of Chemical Engineering. McGi11 University

9. Goldberger, W. M. (1985). Method for the continuous production of carbides: pat. 4543240 US : C01B31/36/; Superior Graphite Co.№ 06/691076

10. Borodulya, V. A., Vinogradov, L. M., Grebenkov, A. Zh, \& Mikhailov, A. A. (2017). Sposob i ustanovka dlya polucheniya carbide kremniya: pat. 2015/EA/0077 BY : C01B 31/36/; Gosudarstvenoye nauchnoye uchrezhdeniye "Institutteplo- i massoobmena im. A.V. Lykova Natsionalnoy academii nauk Belarusi" - № 027539

11. Alekseeva, T. I., Galevskii, G. V., Rudneva, V. V., \& Galevskii, S. G. (2017). Technologicheskiye resheniya $\mathrm{v}$ proizvodstve carbide tsirkoniya: analiz, otsenka, sostoyaniya i perspective. Nauchno-technicheskiye vedomosti SPbGPU, 23(1), 256-270

12. Knowlton, T. M., Pulsifer, A. H., \& Wheelock, T .D. (1969). Coal char gasification in an electrofluid reactor. Ind. Eng. Chem. Process Des. Dev, 8(4), 539.

13. Tanaka, Y. (1962). Electric direct heating method metallic pieces: pat. 306034 US : H05B3/60/; TO A KAKO KK - № US3060304A

14. Manieh, A., Scott, D. S., \& Spink, D. R. (1974). Electrothermal Fluidized Bed Chlorination of Zircon. The Canadian Journal of Chemical Engineering, 52, 507-514

15. Kazhan, A.P., Bogomolov, V.A., Hovavko, A.I., Bondarenko, B.I., \& Simeyko, K.V. (2012). Issledovaniye processa polucheniya vodoroda pyrolizom uglevodorodov $\mathrm{v}$ apparate $\mathrm{c}$ electrotermicheskim psevdoozhizhenym sloem. Energotehnologii i resursosberezheniye, (2), 27-31

16. Bogomolov, V. A., Kazhan, A. P., Bondarenko, B. I., Hovavko, A. I., \& Simeyko, K. V. (2013). Kapsulirovaniye kvartsevogo peska pir- 
ouglerodom $\mathrm{v}$ electrotermicheskom psevdoozhizhennom sloye. Energotehnologii $i$ resursosberezheniye, (5), 33-36

17. Kozlov, A. Chudnovsky, Ya., Khinkis, M., Yuan, H., \& Mark, Z. M. (2014). Advanced Green Petroleum Coke Calcination in an Electrothermal Fluidized Bed Reactor. EPD Congress 204, 17 January 2014

18. Johnson, P. H. (1970). Electrothermic fluidzed bed process: pat. 3499947A US : B01J8/42/; Phillips Petroleum Co - № US3499947A

19. Johnson, H. S. (1961). Electrothermic fluidzed bed apparatus: pat. US3006838A: B01J8/42/; Shawinigan Chemicals Ltd - № US759769A

20. Antonishin, N. V., Borodulya, V. A., Nikitin, V. S., \& Martynov, O. H. (1986). Reactor s electrotermicheskim kipyaschem sloyem: pat. SU 1223989A : B01J 8/18/; Institut teplo- i masoobmena im. A. V. Lykova Natsionalnoy akademii nauk Belarusi - № 027539

21. Bogomolov, V. O., Bondarenko, B. I., Kozhan, O. P., \& Simeyko, K. V. (2013). Reaktor dlya pirolizu gazopodibnyh vuglevodniv: pat. UA 83147: C 10 G 9/32/; Institut gazu NAN Ukrainy № u 201303318

22. Kozhan, O. P., Simeyko, K. V., Dmitriyev, V. M., \& Bondarenko, B. I. (2017). Reaktor dlya vysokotemperaturnykh protsesiv u psevdozridzhenomu shari: pat. UA 117157: B01J 8/18/; Instytut hazu NAN Ukrayiny - № a 201306499

23. Sevryukov, V. N., \& Martyushin, I. G. (1966). Aparat dlya neposredstvennogo nagreva psevdoozhizhennogo sloya: pat. SU 181211: $21 \mathrm{~N}$, 15/02/- № 181211

24. Nekhamin, S. M. (2018). Sposob elektrotermicheskoy pererabotki dispersnogo materiala $\mathrm{v}$ psevdoozhizhennom sloye i ustroystvo dlya yego osushchestvleniya: pat. 2663425 RU: B01J8/18/

25. Markel, R. F., Greenville, S. C., Goldberger, W. M. (1979). Method for heat treating carbonaceous materal in a fluidzed bed: pat. 4160813

\section{US : C10B19/00/; Graphite Synthesis Co.-} № US59211875A

26. Mark, Z. M., Harrison, W. M., \& Doninger, J. E. (2005). Method and apparatus for heat treatment of particulates in an electrothermal fluidized bed furnace and resultant products: pat. US20050062205A1: F27B15/10/; Superior Graphite Co - № US10/666,614

27. Fedorov, S. S., Hubynskyy, M. V., \& Forys, S. M. (2016). Reaktor dlya vysokotemperaturnykh protsesiv u psevdozridzhenomu shari: pat. UA 108964: F27B 15/00/; Natsionalna metalurhiyna akademiya Ukrayiny - № u 201500065

28. Fedorov, S.S., Hubynskyy, M.V., Forys, S.M., \& Hohotsi, O.H. (2016). Elektrotermichna pich psevdozridzhenoho sharu: pat. UA 107972: F27B 15/00/; Natsionalna metalurhiyna akademiya Ukrayiny - № u 201600086

29. Fedorov, S. S., Gubinskiy, M. V., \& Foris, S. N. (2014). Vybor razmerov rabochego prostranstva elektrotermicheskikh pechey kipyashchego sloya dlya pererabotki uglerodnykh materialov. Metallurgicheskaya $i$ gornorudnaya promyshlennost, (4), 87-90

30. Kervalishvili, Z. Ya., Olshanov, Ye. Ya., Parava, G. A., Sevryukov, V. N., Sergeyev, A. L., Sukimskiy, A. I., \& Kholin, M.N. (1983). Reaktor s elektrotermicheskim kipyashchim sloyem: pat. SU 1003878: B01J 8/18/; Moskovskiy institut khimicheskogo mashinostroyeniya - № 1003878

31. Antonishin, N. V., Zabrodskiy, S. S., Nemkovich, V. A., Nikitin, V. S., \& Borodulya, V. A. (1974). Ustanovka s elektrotermicheskim kipyashchim sloyem: pat. SU 423861: F27D 11/10/; Institut teplo- i massoobmena im. A.V. Lykova Natsionalnoy akademii nauk Belarusi - № 423861

32. Mukhlenova, I. P., Sazhina, B. S., \& Frolova, V. F. (Eds). (1986). Raschety apparatov kipyashchego sloya: Spravochnik. Leningrad: Khimiya

Сибір Артем Віталійович, доцент, кандидат технічних наук, доцент кафедри екології, теплотехніки та охорони праці, Національна металургійна академія України, м. Дніпро, Україна. ORCID: 0000-0002-9974-0636. E-mail: artem.sybir@gmail.com

Губинський Михайло Володимирович, професор, доктор технічних наук, ТОВ «ТЕРМАЛ ЕНД METIPIAЛ ЕНЖIHIPIHГ CЕНTЕР», м. Дніпро, Україна. ORCID: 0000-0003-3770-4397. E-mail: gubinm58@gmail.com

Федоров Сергій Сергійович, доцент, доктор технічних наук, Національна металургійна академія, професор кафедри енергетичних систем та енергоменеджменту України, м. Дніпро, Україна. ORCID: 0000-0002-5409-882X. E-mail: fedorov.pte@gmail.com

Губинський Семен Михайлович, ТОВ «ТЕРМАЛ ЕНД МЕТІРІАЛ ЕНЖІНІРІНГ СЕНТЕР», м. 
Дніпро, Україна. ORCID: 0000-0002-4598-5136. E-mail: senja-g@ukr.net

Гогоці Олексій Георгійович, аспірант, Національна металургійна академія України, м. Дніпро, Україна. ORCID: 0000-0002-3173-4432. E-mail: agogotsi@mrc.org.ua

\section{ПЕЧІ 3 ЕЛЕКТРОТЕРМІЧНИМ КИПЛЯЧИМ ШАРОМ. КОНСТРУКТИВНІ ОСОБЛИВОСТІ}

Мета: Метою статті є критичний аналіз та систематизація печей з електротермічним киплячим шаром, які використовуються у низько- та високотемпературних технологічних процесах у металургійній та хімічний промисловості, а також визначення конструктивних особливостей цих пічних агрегатів.

Методика: Критичний аналіз конструкцій високотемпературних установок з електротермічним киплячим шаром на основі світового доробку в галузі графітації та рафінування вуглецевих матеріалів з метою отримання високочистого батарейного графіту.

Результати: За результатами проведеного дослідження та критичного аналізу літературних джерел, авторами запропонована класифікація електротермічних печей киплячого шару: за температурним режимом - низько- та високотемпературні установки; та за на напрямом руху електричного струму між електродами печі крізь шар оброблюваного матеріалу - агрегати із горизонтальним та вертикальним рухом струму. Визначено відмінні особливості у схемах підведення газу та проаналізовано способи завантаження / вивантаження матеріалу.

Наукова новизна: Вперше визначено взаємозв'язок можливих конструктивних характеристик електротермічних печей киплячого шару з температурним режимом їх експлуатації.

Практична цінність: Результати роботи являють собою систематизований науково-технічний матеріал корисний для науковців, дослідників та інженерів задіяних в розробці нових технологій та експлуатації наявних пічних установок на основі електротермічного киплячого шару.

Ключові слова: високотемпературні технологічні процеси, електротермічна піч, киплячий шар.

Artem Sybir, Candidate of Technical Sciences, Associate Professor of Department of Ecology, HeatTransfer and Labour Protection, National Metallurgical Academy of Ukraine, Dnipro, Ukraine. ORCID: 0000-0002-9974-0636. E-mail: artem.sybir@gmail.com

Mykhailo Hubynskyi, Doctor of Technical Sciences, Professor, Thermal \& Material Engineering Center Ltd., Dnipro, Ukraine. ORCID: 0000-0003-3770-4397. E-mail: gubinm58@gmail.com

Serhii Fedorov, Doctor of Technical Sciences, Professor of the Department of Energy Systems and Energy Management, National Metallurgical Academy of Ukraine, Dnipro, Ukraine. ORCID: 0000-00025409-882X. E-mail: fedorov.pte@gmail.com

Semen Hubynskyi, Thermal \& Material Engineering Center Ltd., Dnipro, Ukraine. ORCID: 00000002-4598-5136. E-mail: senja-g@ukr.net

Oleksii Gogotsi, graduate student, National Metallurgical Academy of Ukraine, Dnipro, Ukraine. ORCID: 0000-0002-3173-4432. E-mail: agogotsi@mrc.org.ua

\section{FURNACES WITH ELECTROTHERMAL FUIDIZED BED. PECULIARITIES OF DESIGN}

Purpose: The purpose of the article is critical analysis and classification of furnaces based on an electrothermal fluidized bed, which are used in low- and high-temperature technical processes in the metallurgical and chemical industries, as well as determining the design features of these furnace units.

Methodology: Critical analysis of high-temperature unites' designs, utilizing an electrothermal fluidized bed, is based on world experience in graphitization and refining of carbon materials for production of high-purity battery grade graphite.

Results: As a result of the study and critical analysis of relevant publications, the authors proposed a classification of electrothermal fluidized bed furnaces: by temperature operating mode - low and high temperature units; by the direction of electric current between furnace electrodes through the layer of processed material - units with horizontal and vertical current flow. The distinctive features in gas supply schemes are 
determined and the methods of loading / unloading material are analyzed.

Originality: For the first time, the relationship between the design characteristics of electrothermal fluidized bed furnaces and temperature operating modes has been determined.

Practical implications: The results of the work constitute a systematized scientific and technical material useful for researchers and engineers involved in development of new technologies and operation of existing furnace unites based on an electrothermal fluidized bed.

Keywords: high-temperature processes in technologies, electro-thermal furnace, fluidized bed.

Сибирь Артем Витальевич, доцент, кандидат технических наук, доцент кафедры экологии, теплотехники и охраны труда, Национальная металлургическая академия Украины, г. Днепр, Украина. ORCID: 0000-0002-9974-0636. E-mail: artem.sybir@gmail.com

Губинский Михаил Владимирович, профессор, доктор технических наук, ООО "ТЕРМАЛ ЕНД МЕТИРИАЛ ЕНЖИНИРИНГ СЕНТЕР", г. Днепр, Украина. ORCID: 0000-0003-3770-4397. E-mail: gubinm58@gmail.com

Федоров Сергей Сергеевич, доцент, доктор технических наук, профессор кафедры энергетических систем и энергоменеджмента, Национальная металлургическая академия Украины, г. Днепр, Украина. ORCID: 0000-0002-5409-882X. E-mail: fedorov.pte@gmail.com

ГУбинский Семен Михайлович, ООО "ТЕРМАЛ ЕНД МЕТИРИАЛ ЕНЖИНИРИНГ СЕНТЕР", Г. Днепр, Украина. ORCID: 0000-0002-4598-5136. E-mail: senja-g@ukr.net

Алексей Георгиевич Гогоци, аспирант, Национальная металлургическая академия Украины, г. Днепр, Украина. ORCID: 0000-0002-3173-4432. E-mail: agogotsi@mrc.org.ua

\section{ПЕЧИ С ЭЛЕКТРОТЕРМИЧЕСКИМ КИПЯЩИМ СЛОЕМ. КОНСТРУКТИВНЫЕ ОСОБЕННОСТИ}

Цель: Целью статьи является критический анализ и систематизация печей с электротермическим кипящим слоем, которые используются в низко- и высокотемпературных технологических процессах в металлургической и химической промышленности, а также определение конструктивных особенностей этих печных агрегатов.

Методика: Критический анализ конструкций высокотемпературных установок с электротермическим кипящим слоем на основе мирового опыта в графитации и рафинировании углеродных материалов с целью получения высокочистого батарейного графита.

Результаты: По результатам проведенного исследования и критического анализа литературных источников, авторами предложена классификация электротермических печей кипящего слоя: по температурным режимам - низко- и высокотемпературные установки; по направлению движения электрического тока между электродами печи сквозь слой обрабатываемого материала - агрегаты с горизонтальным и вертикальным движением тока. Определены особенности в схемах подведения газа и проанализированы способы загрузки / выгрузки материала.

Научная новизна: Впервые определена взаимосвязь возможных конструктивных характеристик электротермических печей кипящего слоя с температурным режимом их эксплуатации.

Практическая значимость: Результаты работы представляют собой систематизированный научно-технический материал полезный для исследователей и инженеров при разработке новых технологий и эксплуатации имеющихся печных установок на основе электротермического кипящего слоя.

Ключевые слова: высокотемпературные технологические процессы, электротермическая печь, кипящий слой. 